\title{
Correction to: First-line exome sequencing in Palestinian and Israeli Arabs with neurological disorders is efficient and facilitates disease gene discovery
}

\author{
Holger Hengel (1) - Rebecca Buchert $(\mathbb{D} \cdot$ Marc Sturm - Tobias B. Haack - Yvonne Schelling - Muhammad Mahajnah • \\ Rajech Sharkia - Abdussalam Azem - Ghassan Balousha - Zaid Ghanem • Mohammed Falana (D) Osama Balousha • \\ Suhail Ayesh · Reinhard Keimer - Werner Deigendesch · Jimmy Zaidan · Hiyam Marzouqa - Peter Bauer (D) \\ Ludger Schöls
}

Published online: 28 May 2021

(c) The Author(s) 2021. This article is published with open access

Correction to: European Journal of Human Genetics https://doi.org/10.1038/s41431-020-0609-9

The article "First-line exome sequencing in Palestinian and Israeli Arabs with neurological disorders is efficient and facilitates disease gene discovery," written by Holger Hengel et al., was originally published electronically on the publisher's internet portal on 25 March 2020 without open access. With the author' decision to opt for Open Choice the copyright of the article changed on 17 May 2021 to (C) Author(s) 2020 and the article is forthwith distributed under a Creative Commons Attribution 4.0 International License, which permits use, sharing, adaptation, distribution, and reproduction in any medium or format, as long as you give appropriate credit to the original author(s) and the source, provide a link to the Creative Commons licence, and indicate if changes were made. The images or other third party material in this article are included in the article's Creative Commons licence, unless indicated otherwise in a credit line to the material. If material is not included in the article's Creative Commons licence and your intended use is not permitted by statutory regulation or exceeds the permitted use, you will need to obtain permission directly from the copyright holder. To view a copy of this licence, visit http://creativecommons.org/licenses/by/4.0.

Open access funding enabled and organized by Projekt DEAL.

The original article has been corrected.

Open Access This article is licensed under a Creative Commons Attribution 4.0 International License, which permits use, sharing, adaptation, distribution and reproduction in any medium or format, as long as you give appropriate credit to the original author(s) and the source, provide a link to the Creative Commons license, and indicate if changes were made. The images or other third party material in this article are included in the article's Creative Commons license, unless indicated otherwise in a credit line to the material. If material is not included in the article's Creative Commons license and your intended use is not permitted by statutory regulation or exceeds the permitted use, you will need to obtain permission directly from the copyright holder. To view a copy of this license, visit http://creativecommons. org/licenses/by/4.0/. 